$\left.\begin{array}{llll}1 & 2 & 8 & .1\end{array}\right]$

\title{
The New Unhistoricism in Queer Studies
}

\author{
VALERIE TRAUB
}

VALERIE TRAUB, the Frederick G. L. Huetwell Professor of English and Women's Studies at the University of Michigan, Ann Arbor, is the author of The Renaissance of Lesbianism in Early Modern England (Cambridge UP, 2002), Desire and Anxiety: Circulations of Sexuality in Shakespearean Drama (Routledge, 1992), and the forthcoming Making Sexual Knowledge: Thinking Sex with the Early Moderns (U of Pennsylvania P).
For David Halperin

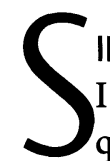

INCE AROUND 2005 A SPECTER HAS HAUNTED THE FIELD IN WHICH

I work: the specter of teleology. In attempting to promote a queerer historiography, some queer studies scholars of French and English early modern literature have charged other queer studies scholars with promoting a normalizing view of sexuality, history, and time. This normalization allegedly is caused by unwitting imprisonment within a framework of teleology. A teleological perspective views the present as a necessary outcome of the past-the point toward which all prior events were trending. The antiteleologists challenge any such proleptic sequence as a straitjacketing of sex, time, and history, and they announce their critique as a decisive break from previous theories and methods of queer history (especially Foucault-inspired genealogy). Given the high profile of the scholars involved, as well as the high octane of their polemics, it is not surprising that their assessment has been embraced enthusiastically by many other scholars, inside and outside early modern literary studies, who aim "to free queer scholarship from the tyranny of historicism." Whereas there are other hot topics in queer studies right now-including the question of whether queer theory should "take a break" from feminism, whether it should "just say no" to futurity, whether it is impervious to racial and class diversity, and whether the moment of queer theory is over-these are all subject to debate in various forums, from conferences and blogs to books and journals. What is curious about this queer teleoskepticism is that no one has responded to the charge that queer historicism is necessarily teleological-and thus there has been a notable absence of debate. ${ }^{2}$

It thus seems important to ask: of what does this queer critique of teleology consist? How did it evolve? What strategies and solutions

(C) 2013 VALERIE TRAUB

PMLA 128.1 (2013), published by the Modern Language Association of America

21 
are being proposed, and what is their analytic and political purchase on the relations among sex, time, and history? Using the accusation of teleology as an analytic fulcrum, I parse in what follows some of the assumptions regarding temporality, representation, periodization, empiricism, and historical change implicit in the alleged relation of teleological thinking to what has been called "straight temporality." Ascertaining the conceptual work that the allegation of teleology performs, I reconsider the meanings and uses of the concept queer, as well as homo and hetero, in the context of historical inquiry. I also assess some of the unique affordances of psychoanalysis and deconstruction for the history of sexuality. At stake, I hope to show, are not only our emerging understandings of the relations between chronology and teleology, sequence and consequence, but also some of the fundamental purposes and destinations of queering.

The scholarship I review here is part of a broader trend in queer studies. Variously called the turn toward temporality or the elucidation of queer time, a range of work across disciplines and periods has focused on time's sexual politics. Shifting away from the spatial modes underwriting much previous scholarship (e.g., theories of intersectionality and social geography), important books have explored backward emotional affects, lateral queer childhoods, and reproductive futurism (Love; K. Stockton; Edelman, No Future). ${ }^{3}$ Although diverse in topic and method, this scholarship argues that temporal and sexual normativities, as well as temporal and sexual dissonance, are constitutively intertwined. Queer temporality, in the words of Annamarie Jagose, is "a mode of inhabiting time that is attentive to the recursive eddies and back-to-the-future loops that often pass undetected or uncherished beneath the official narrations of the linear sequence that is taken to structure normative life" (158). This curvature of time has fueled epistemological and methodological innovations, productively disturbing developmental and progressive schemas whether such schemas are conceived in psychological, narratological, social, or historical terms. Nonetheless, the theoretical rationales, specific methodologies, and political payoff of this bending of time are far from clear. Indeed, even to speak of a turn may unduly homogenize scholarly projects that are keyed to different disciplinary registers and that display varying investments in the history of sexuality, in literary criticism, and in cultural studies. Some scholars working on queer temporality seem motivated by resistance to narratives of the history of sexuality, while others seem interested in time but not history. Some are speaking to debates about historical method in their historical periods, while others are speaking primarily to other queer studies scholars. The relation between studies of queer temporality and "the literary"-as a source for accessing history and temporality-varies as well. Despite its heterogeneity, teleoskepticism is proffered in much of this work as a potent challenge to heteronormativity and "straight time."

To my mind, the broad claims of theory, however intrinsically interesting or valuable, are best assessed in their applicability to specific historical contexts and fields of inquiry. For this reason, I scrutinize the arguments of three early modernists who maintain that teleological thinking present in queer historicism undergirds a stable edifice of temporal normativity. The intense critique of teleology that has arisen in early modern studies is partly due to scholars' efforts to contend with the force of historicism, which has been the field's dominant (but by no means exclusive) method since the 1980s. Furthermore, pre- and early modern studies have been the site of vigorous debate about historiographic method since volume 1 of Michel Foucault's The History of Sexuality upped the critical ante on understandings of sexual modernity. The arguments described in these pages thus emerge from a distinct temporal and profes- 
sional frame, and I leave to others the task of assessing whether my perspective generates questions pertinent to the explanatory potential of queer temporality more generally.

Many of the recent writings of Carla Freccero (who works mainly in French literature and culture) and Jonathan Goldberg and Madhavi Menon (whose expertise is in English literature and culture), including some of their assertions regarding temporality, are trenchant and thought-provoking. The quick uptake of their interventions bespeaks enormous enthusiasm among a diverse range of scholars. What follows unavoidably involves some generalization that elides differences among them (especially on the role of gender and psychoanalysis) and fails to convey the insight and verve with which they read particular texts and cultural phenomena. My impetus for treating them as a collective stems from the fact that they have vigorously published on this theme and, despite their differences, share a common line of argumentation regarding teleology, a subject about which they regularly and approvingly cite one another's views. Furthermore, they are treated by other scholars as providing a unified perspective on this subject. The point is not to attack individual scholars, delineate strict methodological camps, or propose a single way of doing the history of sexuality. Indeed, some recent pronouncements by Freccero, Goldberg, and Madhavi run against the grain of their previous work and thus might be best approached as knowledge in the process of formation. ${ }^{4}$ My aim, then, is to advance a more precise collective dialogue on the unique affordances of different methods for negotiating the complex links among sexuality, temporality, and history making. If I answer critique with critique and, in the end, defend genealogical approaches to the history of sexuality-arguing that we can read chronologically without straitjacketing ourselves or the past-I hope to do justice to these scholars' innovations by engaging seri- ously with their polemics and acknowledging the value of certain hermeneutic strategies for which they are eloquent advocates.

In many respects, the projects of these early modernists reiterate familiar queer theoretical investments. They share with countless others a desire to promote the analytic capacity of queer to deconstruct sexual identity, to illuminate the lack of coherence or fixity in erotic relations, and to highlight the radical indeterminacy and transitivity of both erotic desire and gender. Like many others, they find their warrant in Eve Kosofsky Sedgwick's assertion that "one of the things that 'queer' can refer to" is "the open mesh of possibilities, gaps, overlaps, dissonances and resonances, lapses and excesses of meaning when the constituent elements of anyone's gender, of anyone's sexuality aren't made (or can't be made) to signify monolithically" (Tendencies 8). Drawing on Sedgwick as well to privilege the universalizing over the minoritizing aspect of sexualities, ${ }^{5}$ these critics maintain that we should not "take the object of queering for granted" (Goldberg and Menon 1616). In Freccero's words, her own "work has been mostly about advocating for queer's verbally and adjectivally unsettling force against claims for its definitional stability, so theoretically anything can queer something, and anything, given a certain odd twist, can become queer" ("Queer Times" 485). In historiographic terms, these critics refuse to countenance the emphasis on historical difference often attributed to historicists. In their PMLA article "Queering History" (2005), for instance, Goldberg and Menon call for "acts of queering that would suspend the assurance that the only modes of knowing the past are either those that regard the past as wholly other or those that can assimilate it to a present assumed identical to itself." They also share a resistance to the conventional historical periodizations that typically organize the disciplines of history and literature: "We urge," Goldberg and Menon 
say, "a reconsideration of relations between past and present that would trace differential boundaries instead of being bound by and to any one age" (1616).

Although similar statements appear in the historical work of other scholars, including some they critique, Freccero, Goldberg, and Menon charge these scholars with a failure to deliver. According to Menon, "the ideal of telos continues to shape even the least homonormative studies of Renaissance sexuality" ("Spurning" 496). According to Freccero, "what most resist[s] queering in my field ... [is] a version of historicism and one of its corollaries, periodization" ("Queer Times" 485). And, according to Goldberg, other queer-historicist scholars "remain devoted to a historical positivity that seems anything but the model offered by queer theory" ("After Thoughts" 502). In the view of Freccero, Goldberg, and Menon, the alleged "ideal of telos"-and its reputed corollaries, periodization and positivism-underwrites work governed by a genealogical intent that treats any earlier figures (e.g., the sodomite, the tribade, the sapphist) as precursors of, in Freccero's words, a "preemptively defined category of the present ('modern homosexuality')" (Queer 31). Stating that they find a lingering attachment to identity that unduly stabilizes sexuality and recruits earlier sexual regimes into a lockstep march toward the present, they adduce in others' work a homogeneous fiction of "modern homosexuality" that inadvertently, and through a kind of reverse contamination, conscripts past sexual arrangements to modern categories. And although certain deconstructive tendencies motivate much queer historical scholarship, these critics are further distinguished by the manner in which they champion the capacities of formal textual interpretation-especially the techniques of deconstruction and psychoanalysis-to provide a less teleological, less identitarian, and, in their view, less normalizing historiographic practice. The alluring name that Goldberg and
Menon give to their counterstrategy is "homohistory," defined as a history that "would be invested in suspending determinate sexual and chronological differences while expanding the possibilities of the nonhetero, with all its connotations of sameness, similarity, proximity, and anachronism" (1609). In sum, they call for a queering of history that would be an "unhistoricism"-or, to use Freccero's term, an "undoing" of the history of homosexuality (in ironic homage to David Halperin's How to Do the History of Homosexuality, a main target of her critique [Queer 31-50]).

This critique of queer historicism has a history of its own. Although the question of teleology in organizing historical understanding has long vexed historians, ${ }^{6}$ this question gained momentum in queer studies by means of Sedgwick, who, in Epistemology of the Closet, proposed as her axiom 5 that " $\mathrm{t}] \mathrm{he}$ historical search for a Great Paradigm Shift may obscure the present conditions of sexual identity" (44). Directed at the work of several gay male historians, Sedgwick's critique focused not only on the work of Foucault but also on Halperin's One Hundred Years of Homosexuality, with its social-constructionist effort to differentiate premodern forms of sexual desire and behavior from a distinctively modern homosexual identity. Comparing Halperin's work to Foucault's, Sedgwick observed that "[i]n each history one model of same-sex relations is superseded by another, which may again be superseded by another. In each case the superseded model then drops out of the frame of analysis." Sedgwick's critique of the "birth of the homosexual" and the model of supersession to which it was joined had as its ultimate goal the recognition of the "unrationalized coexistence" of incommensurate models of sexuality: "the most potent effects of modern homo/heterosexual definition tend to spring precisely from the inexplicitness or denial of the gaps between longcoexisting minoritizing and universalizing, 
or gender-transitive and gender-intransitive, understandings of same-sex relations" (47). Concerned with what she termed the "unfortunate side effect" created by historical studies (despite their "immense care, value, and potential"), she noted that whereas "homosexuality as we conceive of it today...' has provided a rhetorically necessary fulcrum point for the denaturalizing work on the past done by many historians," such formulations risked "reinforcing a dangerous consensus of knowingness about the genuinely unknown" in modern discourses of sexuality (45).

Sedgwick's critique had two conceptual targets: narratives of supersession, in which each prior term drops out, and the conceptual consolidation of the present (or the modern). A third target-the perceived emergence of the homosexual locatable in a specific historical moment-can be inferred from the irony that limns her use of the descriptive terms birth and Great Paradigm Shift. Compelling as her critique was, however, Sedgwick did not endorse a particular form of historiography. She did not assert the likelihood of transhistorical meanings, make arguments about historical continuity and change, or advocate synchronic over diachronic methods. Despite other scholars' characterization of her critique as a "refusal of the model of linearity and supersession" (Goldberg, "After Thoughts" 503), she did not address temporal linearity or chronology per se, much less advance a standard of total chronological suspension. By attending to the "performative space of contradiction," Sedgwick deployed deconstructive strategies in her encounter with the past not as a way of doing history but rather "to denaturalize the present" (48).

In How to Do the History of Homosexuality, Halperin responded to Sedgwick's discussion of the "Great Paradigm Shift," offering a pluralist model of four distinct paradigms of male gender and eroticism, all of which, he argues, are subsumed by or conflated with the modern category of homosexuality. Answer- ing Sedgwick's objection regarding supersession, while also integrating her primary insight about synchronic incoherence, Halperin writes:

A genealogical analysis of homosexuality begins with our contemporary notion of homosexuality, incoherent though it may be, not only because such a notion inevitably frames all inquiry into same-sex sexual expression in the past but also because its very incoherence registers the genetic traces of its own historical evolution. In fact, it is this incoherence at the core of the modern notion of homosexuality that furnishes the most eloquent indication of the historical accumulation of discontinuous notions that shelter within its specious unity. The genealogist attempts to disaggregate those notions by tracing their separate histories as well as the process of their interrelations, their crossings, and, eventually, their unstable convergence in the present day.

In other words, Halperin's genealogy is committed to the view that modern sexual categories provide not just an obstacle to the past but also a window onto it. In positioning the present in relation to the past, a queer genealogist might adduce similarities or differences, continuities or discontinuities, all in pursuit of the contingency of history.

In the decade between Sedgwick's critique and Halperin's response, skepticism about the functions of historical alterity and periodization grew among pre- and early modernists. In 1996 Freccero and Louise Fradenburg challenged queer historicists to "confront the pleasure we take in renouncing pleasure for the stern alterities of history." Rejecting as essentialist the insistence on the radical incommensurability of past and present sexualities, they proposed a historiographic practice conscious of the role of desires and identifications across time. Echoing Sedgwick in asking, "Is it not indeed possible that alteritism at times functions precisely to stabilize the identity of 'the modern'?," they argued that 
"it might, precisely, be more pleasurable and ethically resonant with our experience of the instabilities of identity-formation to figure a particular historical 'moment' as itself fractured, layered, indeed, historical" (xix). Related motives animated the work of Carolyn Dinshaw, who sought to "show that queers can make new relations, new identifications, new communities with past figures who elude resemblance to us but with whom we can be connected partially by virtue of shared marginality, queer positionality" (39). Dinshaw's "sensible" historiography, which depended on a "process of touching, of making partial connections between incommensurate entities" such as the medieval and postmodern, also privileged a view of sexuality as indeterminate, constituted as much by disidentification and misrecognition as by identification and mimesis (54).

Work by scholars like Freccero, Fradenburg, and Dinshaw forged an implicit alliance between two forms of queerness: one directed at subjectivity-affirmatively courting the contingency of desire and rejecting identity's stabilizations-and one directed at historiography, aiming to resist alterity and periodization in favor of similitude, resemblance, and identification. Yet none of these scholars set themselves the task of writing a historical account that traversed large expanses of time. Even as they challenged periodization, their own analyses remained bounded in one or, in Dinshaw's case, two time frames. By offering either a synchronic analysis or one that paratactically juxtaposed and connected modernity with premodernity, they could bracket the question of any intervening time span-indeed, the point was to bracket it. This move enabled affective relations with the past to come powerfully to the fore. But this innovation also allowed these and subsequent scholars to avoid all matters associated with chronology, including how to explain the endurance or recurrence of some of the very similarities that interested them. Propelled by the desire to defamiliarize modern identity categories while finding new affiliations between the past and the present, the emerging field of queer historiography did not, at this point, directly engage with, but rather sidestepped, this central issue.

Only after queer historiography adopted the postcolonial critique of an imperialist Western history did teleology per se gravitate to the center of discussion. In addition to confronting Eurocentrism and its geopolitical exclusions, postcolonial historians and historians of non-Western cultures followed Johannes Fabian in querying the ideological fit between spatial and temporal alterity, whereby spatially othered cultures are judged as inhabiting a time before Western modernity. Metanarratives emanating from the metropole have, indeed, inscribed a version of history as developmental telos, whereby a tight conceptual link exists among modernity, progress, and enlightenment or, inversely, between premodernity and what Anjali Arondekar terms "the time(s) of the primitive in a postcolonial world" (125n2). Among those working on sexuality, the critique of Western time lines focused initially on debating the applicability of Western models of sexual identity to non-Western contexts. Troubling the Foucauldian division between a supposedly Eastern ars erotica and a Western, Christian scientia sexualis, historians of India, China, and the Middle East have refuted the discursive construction of nonWestern sexualities as anterior, traditional, primitive, and inevitably developing toward Western models (Babayan and Najmabadi; Sang; Cuncun). Resisting the "sedimented politics of time" that "often reproduces subjects, critical genealogies, and methodological habits that duplicate the very historiographies we seek to exceed" (124), these scholars are striving toward a decolonization that is archival, methodological, and temporal.

In part because the Middle Ages have been treated as the abject other of modernity, 
medievalists were quick to adopt the postcolonial critique of historical time lines for queer studies. In 2001 Glenn Burger and Steven F. Kruger emphasized the politically fraught relations among the premodern, primitivity, and sexual positioning, calling into question "straight (teleological) narration, causal explanations, and schemes of periodization" (xii). Since then, more scholars working on Western cultures have begun to look beyond sexual identity to ask questions about concepts in the history of sexuality that do and do not cross cultural and historical borders. Querying what such differential presences and absences tell us about culturally distinct modes of comprehending and organizing sexuality, they are exploring how our recognition of them might promote alternative genealogies of sexual modernity. By the middle of the last decade, then, the various strands emerging out of queer theory, pre- and early modern literary studies, and postcolonial history had converged in a critically conscious queer historicism that not only brought the past into provocative relation to the present but also provided powerful incentive for scholars' recognition of the role of similarity and identification in the act of historicizing.

So why do I part company with the new unhistoricism? The unhistoricists' implicit query of genealogy-what might be occluded by it?-is vital and no doubt speaks to a more general fatigue regarding the injunction "always historicize!" Furthermore, I appreciate the critical methods, psychoanalysis and deconstruction, that the unhistoricists employ to oppose the hegemony of historicism. ${ }^{8} \mathrm{I}$ agree that "[p]sychoanalysis, as an analytic, is also a historical method" (Freccero, Queer 4), and I would point to increased appreciation for its utility as one of the more appealing trends in early modern queer criticism (Hammill; Gil; Sanchez; W. Stockton, "How to Do," Playing, and "Shakespeare"; Traub, "Joys," "Making," and "Present Future"). I share, as well, the unhistoricists' interest in the capacity of queer to denaturalize sexual logics and expand the object of study through untoward combinations and juxtapositions; their recognition of the roles that affect, desire, and identification play in the work of historical reconstruction; their confidence in the potential of literary language and literary form to contribute to historical understanding; and their belief that the past can speak meaningfully to the present.

Despite these areas of agreement, I remain unconvinced that a teleological imperative is what impedes our understanding of past sexualities. I thus want to scrutinize how the unhistoricists build their indictment of teleology, first by presenting their projects through their own words. Recognizing that an "altericist reaction" among pre- and early modernists "was undoubtedly necessary insofar as it sought to enable analyses of gender and sexuality rather than foreclose them through a presumption that 'we know whereof we speak,"' Freccero nonetheless worries

that altericism is sometimes accompanied by an older, more familiar claim that periodsthose confections of nineteenth-century disciplinarization in the West-are to be respected in their time- and context-bound specificity. This is the historicism I speak of, the one that, in the name of difference, smuggles in historical periodization in the spirit of making "empirical" claims about gender and sexuality in the European past. ("Queer Times" 487)

Freccero correlates a prior, apparently principled, commitment to alterity (thus, "altericism") with periods (time- and context-bound Western confections), while also suggesting that periodicity becomes the vehicle by which scholars make "empirical" claims. Freccero's formulation "in the spirit of" leaves ambiguous whether periodization necessitates empiricism or empiricism necessitates periodization, but her point seems to be that altericists pass off periodization as something 
empirical, whereas it actually is something conceptual and metaphysical. Whichever way it works, empiricism and periodization are judged to be inimical to queer. I will return to the status of periods and empiricism later, but for now I simply offer Freccero's own description of her project Queer/Early/Modern, which "set itself the task of critiquing historicisms and troubling periodization by rejecting a notion of empirical history and allowing fantasy and ideology an acknowledged place in the production of 'fantasmatic' historiography" ("Queer Times" 488). Approaching historical affects as persistence and repetition and situating subjects in a synchronic and more "promiscuous" relation to temporality, she fashions a historiographic method she calls "[q]ueer spectrality-ghostly returns suffused with affective materiality that work through the ways trauma, mourning, and event are registered on the level of subjectivity and history" (489). As a historiographic method, queer spectrality is a flexible, alluring, and often moving hermeneutic. For instance, Freccero's recent application of spectral (or, as she also calls it, figural) historiography charts the "transspecies habitus" of dogs and humans through their manifestations of violence in colonialism and the contemporary prisonindustrial complex; this reading implicates racism, transnational capital, virile masculinity, queer heterosexuality, and lesbian domestic relations in a complex affective network that is "comparatively queer relative to any progressive, ameliorative rational accounts of historical process" ("Figural Historiography" 48, 61). Rejecting progressive narratives as well as remedy and rationality, Freccero maintains that she is motivated by an ethical impulse to produce queer time by means of "a suspension, a waiting, an attending to the world's arrivals (through, in part, its returns), not as a guarantee or security for action in the present, but as the very force from the past that moves us, perhaps not into the future, but somewhere else" ("Queer Spectrality" 207).
Less devoted to a psychoanalytic concept of fantasy but equally invested in nonidentitarian modes of thought, Goldberg, like Freccero, construes temporality as asynchronic, noncontinuous, and nonidentical. At least since his 1995 essay "The History That Will Be," he has attempted to think beyond periodization, arguing that "historic possibilities must depend upon mobilizations that would be unthinkable if history were segmented across uncrossable divides" ("History" 400). Striving to keep "temporal multiplicity in play," he objects that recent projects in the history of sexuality may "have shown that the present draws upon various incommensurate strands, [but they] have tended nonetheless to divide these strands among previous discrete moments and to draw them in relationship to a consolidated present" ("After Thoughts" 503, 502). "Discrete moments" - that is, periodsare defined by Goldberg not only by their boundedness but also by their relation to a "consolidated present." Periodization thereby is identified with "teleological similarity," which "can imagine the past under the sign of difference, but not the present." Extending "Sedgwick's insistence that any time period is characterized by the "unrationalized coexistence of different models" to the unrationalized coexistence of "different temporalities," he maintains that "the relationship between queer theory and the history of sexuality still remains an unresolved terrain. Or, rather, the resolutions, fastening either on the model of absolute alterity or on the model of ultimate identity, have yet to imagine the possibility of writing a history that attends to the possibility of the non-self-identity of any historical moment" ("After Thoughts" 502-03). Rather than a spectral haunting that seeks a reciprocal relation with the past, Goldberg explores the multitemporality, nonidentity, and noncorrespondence of the early modern, the recognition of which can expose the "imbrication of alternative possibilities within normative sexualities" ("Margaret" 435). In The Seeds of 
Things, Goldberg seeks the queer within the hetero by exploring, as he puts it in a related essay, the "multiple materialisms to be found in early modernity," extending the meaning of queer to a consideration of physics because "queer theory is not and never was just about sex in itself" (“After Thoughts" 504).

Menon makes many of the same theoretical and rhetorical moves as Freccero and Goldberg, but her special interest is in pressing against all forms of desire's confinement, whether that of sexual identity, terminology, literary form, chronological boundaries, or historical method. Because desire, in her view, always exceeds identity and is "synonymous ... with queerness," she "insists that we refrain from identifying sexuality, and revel in pursuing the coils of a desire that cannot be contained in a binary temporal code" (Unhistorical Shakespeare 22, 25). In Unhistorical Shakespeare: Queer Theory in Shakespearean Literature and Film, Menon begins by arguing that "our embrace of difference as the template for relating past and present produces a compulsory heterotemporality in which chronology determines identity" (1). In other words, scholarly attention to historical difference produces a relation to time in which sexual identity is causally related to chronological explanations; correlatively, queer studies scholars who do not suspend all chronology are not only normativizing but also, in her words, "governed by dates" ("Period Cramps" 233). Subjection to the date lines of chronological time is then translated into teleology: "Defined as the doctrine of ends or final causes, teleology depends on a sequence leading to an end that can retrospectively be seen as having had a beginning" (Unhistorical Shakespeare 28). Disrupting this purported causal chain through "homohistory, in which desires always exceed identitarian categories and resist being corralled into hetero-temporal camps," Menon exploits what she sees as the tight congruence of literary form with historical and political struc- tures, to access what she calls, in her book's final sentence, "the homo in us all" $(1-2,142)$. " Her term "compulsory heterotemporality" (1), echoing Adrienne Rich's "compulsory heterosexuality," reactivates sexual normativity as the cause and effect of "straight" temporality and historiography. Adopting the rhetoric of postcolonial studies, Menon writes that " $[t]$ he temporal version of decolonization-what may be termed dechronolization-would involve taking anachronism seriously and defying difference as the underwriter of history" (Reply) ${ }^{10}$ Under the banners of homohistory and unhistoricism, Menon rejects not only historical difference but also what she sees as its theoretically suspect corollaries-facts, origins, authenticity, and citation or naming-to which she believes historicists naively adhere.

Composing what increasingly seems a united front, these scholars resist historicism on the grounds that it exaggerates the self-identity of any given moment and therefore exaggerates the differences between any two moments. Against what they view as a compulsory regime of historical alterity, they elevate anachronism and similitude as the expressions of queer insurgency. Their readings offer persuasive examples of how queerness animates and troubles ostensibly heterosexual literary texts and cultural discourses. Their strengths as critics reside in their ability to see beyond heterosexuality's inscription on textual form as well as their attentiveness to the vicissitudes of desire and the failures of sexuality. Their contributions as theorists include their fashioning of a queer analytic that encompasses a range of relations that do not aspire to any intelligible identity. Furthermore, a deep ethical commitment to deconstructive exposure-as a mode of reading, as politics, as theory-informs their provocations. Whether one applauds, as I do, or abhors, as others might, the political implications of continually exposing identity's contradictions and indeterminacy (a debate now three decades old), their readings amply 
demonstrate the stresses and fractures in the normative, as well as the distinctive ability of literary texts to solicit our awareness of such productive contradictions and indeterminacy.

Readings, however, are not the same thing as history; and deconstructive and psychoanalytic interpretations of literary texts, while they contribute importantly to historical understanding, do not necessarily conduce to a historical explanation. For all the utility of deconstruction, in particular, as an interpretative protocol, these critics overestimate its analytic capacity and explanatory power. Although deconstruction exposes the contingency ofand thus implicitly historicizes - truth claims, the extent to which its largely synchronic hermeneutic can succeed as a full-scale historiographic method remains unresolved. Whereas deconstruction may be an extraordinary technique for elucidating queerness in time, it has not, at least not yet, demonstrated a satisfying facility for analyzing temporality in all its dimensions, including elucidating queerness across time.

So how do these scholars make their argument with such persuasive force? To understand this, we need to attend to the rhetorical maneuvers and conceptual conflations that underlie their indictments of difference, chronology, periodization, and empiricism. First, an associational logic pervades their work, wherein historical difference, chronology, periodization, and empirical facts are positioned in an endlessly self-incriminating and disqualifying feedback loop. These maneuvers and conflations reflect a general tendency toward analogical argumentation. As should be clear from their own words, Goldberg, Menon, and Freccero's rejection of "straight temporality" forges a tight metonymic chain among the alleged operations of sex, time, and history. They link these operations through rhetorical maneuvers whereby difference and sameness are constellated with concepts that stand in as near cognates: not only hetero and homo but also difference and similitude, distance and proximity, multiplicity and self-identity, change and stasis, disidentification and mimesis. These close cognates allude to both abstract theoretical principles and specific material realities. Yet drawn as they are from different epistemological registers-psychic, social, temporal, formal, historiographicand abstracted from contexts of space or time, they are rhetorically deployed to cross seamlessly from one conceptual domain to another. In this unmarked analogical process, a tug on one link of the metonymic chain causes movement in another. However, because these analogies are forged presumptively rather than argued and are sustained by the play of metaphors rather than by discursive or material connections, when the conceptual space or difference between these concepts becomes inconvenient, they are silently sundered-allowing great latitude for equivocation.

It remains unclear why analogical argumentation-familiar to readers of medieval and Renaissance texts as a dominant style of reasoning (Foucault, Order) -might be especially suited to queer analysis. Nor is it clear why the mode of analogical thinking signified by the rhetorical figure metalepsis is heralded by Freccero and Menon as an exemplary queer analytic tool. Metalepsis occurs when a present effect is attributed to a remote cause; it links A to D but only by eliding B and $C$. Since several steps intervene between the cause and effect, metalepsis constitutes a "compressed chain of metaphorical reasoning" (Lanham 99). Metalepsis can be rhetorically powerful, but it is vulnerable to critique as fuzzy logic. Freccero suggests that metalepsis is particularly queer and theoretical: "the reversal signified by the rhetorical term metalepsis could be seen to embody the spirit of queer analysis in its willful perversion of notions of temporal propriety and the reproductive order of things. To read metaleptically, then, would be to engage in queer theorizing" (Queer 2). More interested in the status of metalepsis as a repressed or failed rhetori- 
cal device, Menon uses it to read absent sex scenes in Shakespearean drama, scenes of implied consummation that, despite their failure to be staged, nonetheless link social cause to tragic effect (Wanton Words). While there is much to admire in the way these critics demonstrate that "the 'far-fetched' nature of metalepsis telescopes time so that the far appears near, and vice versa" (Wanton Words 85), their willingness to "embrace the accusation of metalepsis" (Freccero, Queer 2) fails to translate into a cogent defense of metalepsis as a mode of queer argument.

On the contrary, a metaleptic sleight of hand enables the ground of critique to keep shifting. At times it seems that the allegation of teleology is directed against scholars who invoke any form of sexual identity, even if located in the present or construed as indeterminate and internally riven. At other times the accusation appears aimed at scholars' attempts to track terms, concepts, and forms of intelligibility by means of the temporal frame of chronology or diachrony. Sometimes the complaint is that scholars fail to treat sex solely as representation, an interpretative choice that renders them vulnerable to charges of empiricism and positivism. The indictment sometimes widens to encompass the entire discipline of history and the concerns and methods of historians. Through an on-again-off-again associational reasoning dedicated to the wholesale rejection of alterity cum heterotemporality, these investments mingle, merge, and sometimes fall apart.

Recognizing that such rhetorical maneuvers underpin the charge of teleology, we might be justified in asking what forms of similarity are being celebrated, and what kinds of difference are discarded. A case in point is the talismanic invocation of "the homo." Despite the catchy term homohistory, it is unclear how expanding the possibilities of the homo, "with all its connotations of sameness, similarity, proximity, and anachronism," automatically enacts resistance to "a present assumed identical to itself." Nor is it clear why the homo necessarily would be queerer than alterity, unless the corresponding shorthand "hetero" is so essentialized as to be always already normativizing. Might historical alterity not sometimes offer its own pleasures (as well as accurately describe certain pre- and early modern modes of intelligibility)? How is it that the homo signifies similarity and identification across time while signifying resistance to identification with sexual categories in the present? Just what is conveyed, in psychic, social, temporal, formal, and historical terms, by the überconcepts homo and hetero? How much analytic weight and presumed congruence can these master terms and their pseudocognates bear? To what extent are they in sync, when, and why? Unhistoricist scholars use the concepts of homo and hetero as linchpins to suture together diverse phenomena; but these concepts fail to attach to, much less elucidate, specific social conditions or material embodiments.

Sexuality, the diverse enactments of erotic desire and physical embodiment; temporality, the various manifestations of time; and history, historicism, and historiography, the aggregate repertoire of cognitive and affective approaches to the past are not intrinsically connected. Neither straight identity nor heterosexual desire is the same as linear time. Not every diachronic or chronological treatment of temporality needs to be normativizing, nor is every linear arc sexually "straight." A scholar's adherence to chronological time does not necessarily imply a relation to sexuality or normativity. Nor does a scholar's segmentation of time into periods. The act of periodizing is of routinized professional significance, functioning for many historians and literary critics as rote convenience, not to mention as a structure underlying the academic job market. It is worthwhile to question the value of any conceptualization that has been reified in this manner, as well as to insist that scholars recognize their 
complacency and complicity in its arbitrary application. Indeed, it has become common to refer to the act of periodization as "not simply the drawing of an arbitrary line through time, but a complex practice of conceptualizing categories, which are posited as homogenous and retroactively validated by the designation of a period divide" (Davis 3). Periodization produces some unfortunate effects, including tendentious misrecognitions of the exemplarity or novelty of one's chosen purview and falsely universalizing claims that ignore what scholars who study other periods do. But conventional periods are only one means of slicing and dicing the past; time can be segmented in multiple ways, the concept of the period changing according to the question and time frame considered (Blackbourn). To periodize is not to advocate a particular method, and the identity that periodicity imposes need not be inevitably problematic - as long as it is understood to be contingent, manufactured, invested, and not produced by othering what came before. The wholesale characterization of periodization as a straightening of the past races over such issues while making light of historical contingency-that is, the ways in which practices, representations, and discourses happen to gather in specific places and times.

Although certain problematic allegiances among sexuality, temporality, and historiography exist-as when invocations of the future are enrolled in the service of reproductive generation (Edelman, No Future)-these links, far from being immanent in either sex or time, are historically and discursively produced. If temporality has been harnessed to reproductive futurity, this link is di e to an operation of ideology, not to the formal procedures of diachronic method (which, while not exempt from ideology, is not the same as ideology). However coimplicated, mutually reinforcing, and potentially recursive, the relations of sex to time are the effects of a historical process, not the preconditions to history.
We thus need to ask which analytic and material processes make history and historiography teleological, heterotemporal, or straight.

History is heterotemporal not only because each synchronic moment is riddled with multiple, and sometimes contradictory, asynchronicities but also because time, like language, operates simultaneously on synchronic and diachronic axes. Although it is true, as Menon argues, that " $[\mathrm{t}]$ ime does not necessarily move from past to future, backward to forward" ("Period Cramps" 233), it also is true that time moves on. Any ethics we might wish to derive from a consideration of temporality must contend with the irreducible force of time's movement on our bodies, our species, and the planet (Grosz). Queer or not, we remain in many respects in time. Analytics dedicated to charting time's cultural logics can be organized through lines, curves, mash-ups, and juxtapositions. Nonetheless, writing the history of sexuality by means of asynchronicities located in a synchronic frame or by vaulting over huge expanses of time may enable one to bypass chronology, but it generally fails to break out of the binary of "then" and "now" that thus far has constituted queer studies' engagement with the past.

The sequential process that enables and organizes diachrony is, I would argue, a crucial and often tendentious element of sex, texts, and history. Sequence is a formal elaboration, made possible by a syntactic arrangement, used to imply connections, highlight or manage disconnections, and drive a temporal movement along. But sequence in one discursive domain-like narrative or poetic formmay not equate to, or even imply, sequence in another domain, such as the erotic concepts of foreplay or consummation. What is the relation between unconventional literary or cinematic form and queer eroticism? How and why might the operations of sexuality and form be coincident, and what is at stake in apprehending them as identical? ${ }^{11}$ What mechanism or process-aesthetic, erotic, po- 
litical, historical-enables their equation? Are all "points," consummations, and closures (textual, erotic, political, historical) coimplicated, and do their relations all possess the same degree of necessity?

Absent investigation of these questions, the presumptive metonymies of sexuality, temporality, and historiography confuse chronology and consequence with teleological progress. In binding such disparate phenomena into a single unitary ontology, the advocates of homohistory assert, ironically, a new essentialism. To invoke Sedgwick once more, "What if the richest junctures weren't the ones where everything means the same thing?" (Tendencies 6). That these conflations occur under the banner of queer should not go unnoticed. Queer's free-floating, endlessly mobile, and infinitely subversive capacities may be strengths-allowing queer to accomplish strategic maneuvers that no other concept does-but its principled imprecision imposes analytic limitations. At the level of politics, for instance, queer's congeniality with neoliberalism has been well documented (Alderson). However mutable as a horizon of possibility, queer is a position taken up in resistance to specific configurations of gender and sexuality. If queer is intelligible only in relation to social norms, and if the concept of normality itself is of relatively recent vintage (Lochrie), then the relations between queer and these changing configurations of gender and sexuality need to be defined and redefined. To fail to specify the terms of queer's historicity is to ignore desire's emergence from distinct cultural and material arrangements of space and time, as well as from what psychoanalysis calls libidinal predicates. It is to celebrate the instability of queer by means of a false universalization of the normal.

The analytic capacity of queer can only be elevated to ontology if it is abstracted and dehistoricized. One of the more dubious forms its abstraction and dehistoricization take is the insistence that sexual identity is irrelevant to contemporary queer life. Opines Menon, "[A] homosexuality that is posited as chronologically and sexually identifiable adheres to the strictures of heterohistoricism and is therefore not, according to the logic of my argument, queer at all" (Unhistorical Shakespeare 25). Although Goldberg and Freccero have no doubt that sexual identities generate real effects, they tend to interpret them as exclusively pernicious. If, as Lee Edelman maintains, "queerness can never define an identity; it can only ever disturb one" (No Future 17), queerness today nonetheless overlaps with and is tethered to a range of identities, in complex relations of support, tension, and contest. However problematic, regulatory, and incoherent modern identity categories may be, they are palpable and powerful discursively, socially, personally, and politically. That we remain under modernity's sway is clear from contemporary debates about the globalization of gay identity, ${ }^{12}$ as well as from the pervasive institutionalization of sexual identities in laws, social policies, and clinical therapies. For this reason, a queer historicism that refuses, on principle, to countenance the existence of the category of "modern homosexuality" invests too much descriptive accuracy in the truth value of queer theory. ${ }^{13}$

Rather than devolve into a zero-sum game of identity versus nonidentity, queer studies could gain some analytic purchase by recognizing that the material, social, and psychic conditions of queer life may not always be served by the presumption of an exclusive queerness: perhaps at least some of us, and the worlds in which we live, are queer and gay, queer and bi, queer and trans, queer and lesbian, queer and heterosexual. This is a matter of recognizing not only the import of social emplacements and embodied desires-or even the contingency of queer theory itself-but also the give and take of psychic processes. Identities may be fictionsor, in Freccero's term, "phantasm[s]"-but they are weighty ones and still do important 
work. That they also break down, become unhinged, is understood in psychoanalysis as part of a lifelong process of formation and deformation, not an either-or proposition.

To clarify this tension in less psychoanalytic terms, let us return to the theorist who has done more than anyone to render explicit the stakes of a queer hermeneutic. Following her description of the "open mesh of possibilities" with a long list of possible selfidentifications that queer might encompass, Sedgwick notes that "given the historical and contemporary force of the prohibitions against every same-sex sexual expression, for anyone to disavow those meanings, or to displace them from the term's definitional center, would be to dematerialize any possibility of queerness itself" (Tendencies 8). Sedgwick's queer is positioned in relation to universalizing and minoritizing axes; its radical potential is relative to the political work of identity, which is apprised as simultaneously enabling and disabling, self-empowering and disciplinary. As is usual with her caveats, something important is at stake here, politically and ethically. Intent on promoting the universalizing over the minoritizing aspects of eroticism, those who would celebrate "the homo in us all" seem unaware of, or perhaps untroubled by, the asymmetrical disposition of privileges and rights attached to sexualminority status. Furthermore, to argue, as Menon does, that sexual-identity categories are themselves an effect of a misguided queer historicism is to misrecognize the processes by which identities are produced, as well as the political force of their application and dissemination (Unhistorical Shakespeare 3).

Only by failing to attend to historicism as it is actually practiced can an accusation such as Menon's stand. But unhistoricism seems interested more in refiguring abstract temporality than in engaging with history or historiography. Posing unhistoricism against what they call "hegemonic history," Goldberg and Menon take as "axiomatic" (1615-16) the cri- tique of the traditional historical enterprise proffered in Metahistory (1973) by Hayden White, whose work is the primary touchstone for Freccero as well ("Queer Time" 72n13). Their adoption of White's stance against "History" writ large implies that historians have ignored his critique, when in fact it has been widely discussed and to some degree integrated into cultural history, intellectual history, gender history, the history of sexuality, and queer historiography as practiced by historians. The fact that disciplinary history has witnessed a sustained engagement with time and temporality in recent years is also elided in their polemics.

The un of unhistoricism must disregard these engagements in order to produce a binary for the sake of deconstructing it. Moreover, this project bespeaks an antipathy to empirical inquiry that, viewed as the primary tool of the historian, is posed as antithetical to acts of queering - as if queerness could not live in the details of empirical history. Needless to say, plenty of scholars in queer studies do practice various forms of empirical inquiry-not only historians but also anthropologists, sociologists, psychologists, legal theorists, critical race theorists, and, yes, literary critics-and some of them have offered astute analyses of the relation between their methods and those of queer theory. Without delving into that bibliography, one can simply ask, Where would queer theory be without the anthropology of Esther Newton, the history of George Chauncey, the sociology of Steven Epstein, and the legal writings of Janet Halley? Where would queer theory be without Gayle Rubin's “Thinking Sex”? ${ }^{14}$

Rejecting out of hand the methods used by most social scientists, unhistoricism's hostility to empiricism adorns itself with the resurgent prestige of "theory." Freccero proposes not to "take seriously the pieties of the discipline that would require the solemn, even dour, marshalling of empirical evidence" (Queer 3), while Menon laments that "[b]y 
grafting chronological history onto theory, Renaissance queer theorists confine themselves to being historians of sexuality" ("Period Cramps" 234; my emphasis). Rendering explicit the hierarchical division of labor informing their critique, these scholars' elevation of (sexy) theory over (dour) history is never fully explained, nor are key practitioners of the history of sexuality-those trained as historians, those who identify as historians, and those working in history departments-cited and directly engaged. Indeed, one might probe what history stands for in this body of work. For many scholars, history is on the one hand an academic discipline, a knowledge community, and a professional locus from which to investigate the past and on the other hand the collective, highly mediated understandings of material, ideational, and discursive "events" of past cultures, achieved through various methods. ${ }^{15}$ But for the unhistoricists, history stands in for a specific, self-delimiting, and ultimately caricatured set of methods, becoming an abject emblem crowned with a capital letter-in other words, a cliché.

It is not my purpose to mount a defense of the work of historians. Their discipline is as varied and contentious as any literature department's, and its internal debates regarding the "cultural turn," "narrative," "teleology," "evidence," "objectivity," and "theory" are complex, nuanced, and ongoing. Others are doing a better job thinking through the affordances of disciplinary history, including its methods and protocols, for queer endeavors than I ever could (Doan; Clark). And historians of sexuality are more than capable of explaining their own investments and methods (Puff; Herzog). I doubt, however, that historians will direct their explanations to the unhistoricists, for the latters' lack of genuine interest in the discipline of history assures that most historians will feel free to ignore them. The unhistoricists' mischaracterization of the historians' enterprise threatens not only to stall productive exchange between literary and historical studies (thereby contributing to the mutual disciplinary estrangement that in the past produced some of the problems of historical practice so abhorred by the unhistoricists) but also to deflect attention from the substantive methodological challenges still faced by those intent on crafting a queer historicism (Doan; Lanser, "Mapping," "Political Economy," and "Sexuality"; Traub, "Joys," "Making," and "Present Future").

Demeaning the disciplinary methods employed to investigate historical continuity and change does not advance the cause of queerness; nor does the charge of normalization. For those of us committed to nonnormative modes of being and thought, the derision implicit in this accusation can only be construed as an attempt to foreclose any possibility of resistance. ${ }^{16}$ While proclaiming a uniquely queer openness to experimentation and indeterminacy, the unhistoricists disqualify others' ways of engaging with the past, seeing in the effort to account for similarities and change over time only a hegemonic, if defunct, disciplinarity. Paradoxically, unhistoricism arrogates to itself the only appropriate model of queer history even as its practitioners imply that history is not something they are interested in making. The categorical quality of their polemic, which implicitly installs queer as a doctrinal foundation and ideological litmus test, goes to the heart of historiographic and queer ethics. It goes to the heart of academic and queer politics. It goes to the heart of interdisciplinarity and its future.

Rather than practice "queer theory as that which challenges all categorization" (Menon, "Period Cramps" 233), there remain ample reasons to practice a queer historicism dedicated to showing how categories, however mythic, phantasmic, and incoherent, came to be. To understand the arbitrary nature of coincidence and convergence, of sequence and consequence, and to follow them through to the entirely contingent outcomes 
to which they contributed: this is not a historicism that creates categories of identity or presumes their inevitability; it is one that seeks to explain such categories' constitutive, pervasive, and persistent force. Resisting unwarranted teleologies while accounting for resonances and change will bring us closer to achieving the difficult and delicate balance of apprehending historical sameness and difference, continuism and alterity, that the past, as past, presents to us. The more we honor this balance, the more complex and circumspect will be our comprehension of the relative incoherence and relative power of past and present conceptual categories, as well as of the dynamic relations among subjectivity, sexuality, and historiography.

Such a queer historicism need not segregate itself from other methods, such as psychoanalysis, with its crucial recognition of the role of the unconscious in historical life, and its aim may well be the further deconstruction of identity categories. But any such rapprochement with other methods would require enhanced discernment of the ways our bodies remain in time, as well as of the use to which different theories and theorists of sex, time, and history are put. In this regard, the exchange I have attempted to advance in these pages cannot help touching on the generative legacy of Eve Kosofsky Sedgwick. In its citational circulations, that legacy has become ever more diffuse, and at times attenuated or diluted-thus raising the stakes on the question of how we utilize the multiple "Sedgwicks" we have known. No less at stake is how this debate bears on David Halperin's evolving contributions to queer theory and queer history. That this is so gives sufficient reason to pause over the prospect of yoking the future of queer so tightly to unhistoricism. What we create out of the copia bequeathed by Sedgwick-and by those with whom she was in dialogue-merits something more precise, more scrupulous. After all, what we remember, what we forget, what we retain, what we omit, and what we finally acknowledge as our debts-these are no less than history in the making.

\section{NOTES}

I thank Ellen Armour, Crystal Bartolovich, Gina Bloom, Sean Brady, Dympna Callaghan, Peter Cryle, Laura Doan, Ari Friedlander, Melissa Hardie, Annamarie Jagose, Kate Lilley, Karma Lochrie, Jeffrey Masten, Peggy McCracken, Helmut Puff, Mark Schoenfeldt, Kathryn Schwarz, Stephen Spiess, Will Stockton, Lee Wallace, Amanda Winkler, and Patsy Yaeger for their thoughtful engagements with this argument.

1. Nardizzi, Guy-Bray, and Stockton, "Queer Renaissance Historiography" 1 . See also Eisner and Schachter; See; W. Stockton, "How" and Playing. For the current interest in temporality in early modern studies, see Harris. Judging from publications and references at conferences, endorsement of the critique has been nearly universal. One muted exception is Dinshaw and Lochrie, whose letter to the editor of PMLA in response to Goldberg and Menon's essay "Queering History" accepts the general critique of teleology but resists the substitution of early modern for Renaissance and inquires what it might mean to reconstitute scholarly periodization for scholars trained in periods.

2. Dissenting murmurs about the politics of unhistoricism have begun to be articulated in reviews (DiGangi; Radel; W. Stockton, "Shakespeare").

3. See also Freeman, "Theorizing" and Time; Halberstam; Rohy; Muñoz. South Atlantic Quarterly and GLQ have dedicated special issues to queer temporality (Halley and Parker; Freeman, “Theorizing”). Queer temporality was the central topic at Manchester University's 2011 Sexuality Summer School.

4. Goldberg's prior work, e.g., did not eschew all relations of early modern to modern categories: "I have wanted to see how relations between men (or between women or between men and women) in the period provide the sites upon which later sexual orders and later sexual identities could batten" (Sodometries 22).

5. In Epistemology, Sedgwick argues that homohetero definition hinges on a synchronic tension between minoritizing and universalizing axes: homosexuality can be viewed simultaneously as a matter of importance to a small, distinct minority or to all people, regardless of perceived sexual orientation.

6. Hunt discusses historians' problems with teleology.

7. My elucidation of "cycles of salience" enacts my appreciative measure of this body of work, to which I tried to add more-sustained attention to female-female desire ("Present Future"). 
8. The ongoing, dynamic, and often contested relations among historicism, psychoanalysis, and deconstruction, as well as queer theory's indebtedness to each of them, deserve their own genealogy. It is beyond the scope of my argument to anatomize these critics' uses of psychoanalysis and deconstruction, which differ in emphasis, theoretical source, and in synthesis attained; nor is it my intention to pigeonhole them according to theoretical frameworks. These scholars do, however, consistently align deconstruction and psychoanalysis and do not explore possible conceptual tensions between them. Freccero's work is the most programmatic, announcing its fidelity to "psychoanalytic and poststructuralist dimensions of queer theory" (Queer 2) and regularly citing Jacques Derrida and Walter Benjamin. Menon's persistent focus on desire as the excess that disrupts identity cleaves closely to Lacanian understandings, but her readings generally pursue a deconstructive aim. Goldberg's theoretical repertoire, like his oeuvre, is eclectic; his touchstones in The Seeds of Things, e.g., include Michel Serres, Gilles Deleuze, Leo Bersani, and Foucault.

9. This phrase appropriates Bersani's call in Homos for an "anticommunal mode of connectedness" that would not assimilate queers "into already constituted communities" (10). Bersani's meaning of "homos," however, is invested in social specificity.

10. Retheorizing anachronism is of broad interest (Harris; Rohy) and is partially fuelled in early modern studies by the long-standing critique by new historicists of psychoanalysis. Here I can only point out that these critics' treatment of anachronism is paradoxical. On the one hand, they resist the anachronistic imposition of modern identities onto the past; Goldberg, e.g., repeatedly remarks that the early modern period "does not operate under the aegis of the homo/hetero divide" (Introd. 2). On the other hand, they celebrate the way in which anachronism breaks with the niceties of temporal order.

11. Positing analogies between literary (or cinematic) form and sexual (and political) positions has a long history in queer theory (Edelman, Homographesis). In earlymodern-sexuality studies, this strategy informs studies by Bredbeck; Hammill; Haber.

12. Manalansan; Paur; Gopinah; Wah-shan; Rofel; Jeffreys; Alexander.

13. A related point is made, in the context of a different argument, by Wiegman: "let's not assume ... that as a form of internal critique, queer theory bears a truth that identity's inaugural form does not" (120).

14. Rubin, along with Sedgwick, Halperin, and Butler, is often credited with founding queer theory. Epstein has recently highlighted the importance of ethnographic study to "Thinking Sex" ("Thinking").

15. In queer studies there is a pervasive confusion among the terms history (the past), history (the academic discipline), historicism (a particular method, both old and new), historiography (methods in general), the past or pastness, and temporality. Historicism as used in queer studies mainly refers to literary criticism that focuses on historically distant periods, while historians almost never use the term (which for them refers to a "scientific" conception of history as an objective account of the past).

16. This is not to say that we might not want to rethink the stakes of queer theory's self-constellation around antinormalization (Wiegman).

\section{Works Cited}

Alderson, David. "Queer Cosmopolitanism: Place, Politics, Citizenship and Queer as Folk." New Formations 55 (2005): 73-88. Print.

Alexander, M. Jacqui. Pedagogies of Crossing: Meditations on Feminism, Sexual Politics, Memory, and the Sacred. Durham: Duke UP, 2005. Print.

Arondekar, Anjali. “Time's Corpus: On Sexuality, Historiography, and the Indian Penal Code." Hayes, Higonnet, and Spurlin 113-28.

Babayan, Kathryn, and Asfaneh Najmabadi, eds. Islamicate Sexualities. Cambridge: Harvard UP, 2008. Print.

Bersani, Leo. Homos. Cambridge: Harvard UP, 1995. Print.

Blackbourn, David. “'The Horologe of Time': Periodization in History." PMLA 127.2 (2012): 301-07. Print.

Bredbeck, Gregory. Sodomy and Interpretation: Marlowe to Milton. Ithaca: Cornell UP, 1991. Print.

Burger, Glenn, and Steven F. Kruger. Introduction. Queering the Middle Ages. Ed. Burger and Kruger. Minneapolis: $\mathrm{U}$ of Minnesota P, 2001. xi-xxiii. Print.

Clark, Anna. Desire: A History of European Sexuality. New York: Routledge, 2008. Print.

Cuncun, Wu. Homoerotic Sensibilities in Late Imperial China. London: Routledge, 2004. Print.

Davis, Kathleen. Periodization and Sovereignty: How Ideas of Feudalism and Secularization Govern the Politics of Time. Philadelphia: U of Pennsylvania $\mathrm{P}$, 2008. Print.

DiGangi, Mario. "Queer Theory, Historicism, and Early Modern Sexualities." Rev. of Queer/Early/Modern, by Carla Freccero, Before Intimacy: Asocial Sexuality in Early Modern England, by Daniel Juan Gil, Incest and Agency in Elizabeth's England, by Maureen Quilligan, and Constructions of Female Homoeroticism in Early Modern Drama, by Denise A. Walen. Criticism 48.1 (2006): 129-42. Print.

Dinshaw, Carolyn. Getting Medieval: Sexualities and Communities, Pre- and Postmodern. Durham: Duke UP, 1999. Print.

Dinshaw, Carolyn, and Karma Lochrie. Letter. PMLA 121.3 (2006): 837-38. Print.

Doan, Laura. Disturbing Practices: History, Sexuality, and Women's Experience of Modern War. Chicago: $\mathrm{U}$ of Chicago $P$, forthcoming. Print. 
Edelman, Lee. Homographesis: Essays in Gay Literary and Cultural Theory. London: Routledge, 1994. Print.

- No Future: Queer Theory and the Death Drive. Durham: Duke UP, 2004. Print.

Eisner, Martin G., and Marc D. Schachter. "Libido Sciendi: Apuleius, Boccaccio, and the Study of the History of Sexuality." PMLA 124.3 (2009): 817-37. Print.

Epstein, Steven. "Thinking Sex Ethnographically." GLQ A Journal of Lesbian and Gay Studies 17.1 (2011): 85-95. Print.

Fabian, Johannes. Time and the Other: How Anthropology Makes Its Object. New York: Columbia UP, 1983. Print.

Foucault, Michel. The History of Sexuality. Vol. 1. New York: Random, 1976. Print.

- The Order of Things: An Archaeology of the Human Sciences. New York: Random, 1971. Print.

Freccero, Carla. "Figural Historiography: Dogs, Humans, and Cyanthropic Becomings." Hayes, Higonnet, and Spurlin 45-67.

-. Queer/Early/Modern. Durham: Duke UP, 2006. Print. . "Queer Spectrality: Haunting the Past." A Companion to Lesbian, Gay, Bisexual, Transgender, and Queer Studies. Ed. George E. Haggerty and Molly McGarry. Malden: Blackwell, 2007. 194-213. Print.

_ . "The Queer Time of the Lesbian Premodern." The Lesbian Premodern. Ed. Noreen Giffney, Michelle M. Sauer, and Diane Watt. New York: Palgrave, 2011. 61-73. Print.

"Queer Times." South Atlantic Quarterly 106.3 (2007): 485-94. Print.

Freccero, Carla, and Louise Fradenburg. Premodern Sexualities. London: Routledge, 1996. Print.

Freeman, Elizabeth. “Theorizing Queer Temporalities: A Roundtable Discussion." Queer Temporalities. Ed. Freeman. Spec. issue of GLQ: A Journal of Lesbian and Gay Studies 13.2-3 (2007): 177-95. Print.

—. Time Binds: Queer Temporalities, Queer Histories. Durham: Duke UP, 2010. Print.

Gil, Daniel Juan. Before Intimacy: Asocial Sexuality in Early Modern England. Minneapolis: U of Minnesota P, 2006. Print.

Goldberg, Jonathan. "After Thoughts." South Atlantic Quarterly 106.3 (2007): 501-10. Print.

_- "The History That Will Be." GLQ: A Journal of Lesbian and Gay Studies 1.4 (1995): 385-403. Print.

- Introduction. Queering the Renaissance. Ed. Goldberg. Durham: Duke UP, 1994. 1-14. Print.

__. "Margaret Cavendish, Scribe." GLQ: A Journal of Lesbian and Gay Studies 10.3 (2004): 433-52. Print.

- The Seeds of Things: Theorizing Sexuality and Materiality in Renaissance Representations. New York: Fordham UP, 2009. Print.

Sodometries: Renaissance Texts, Modern Sexualities. Stanford: Stanford UP, 1992. Print.
Goldberg, Jonathan, and Madhavi Menon. "Queering History.” PMLA 120.5 (2005): 1608-17. Print.

Gopinah, Gayatri. Impossible Desires: Queer Diasporas and South Asian Public Cultures. Durham: Duke UP, 2005. Print.

Grosz, Elizabeth. The Nick of Time: Politics, Evolution, and the Untimely. Durham: Duke UP, 2004. Print.

Haber, Judith. Desire and Dramatic Form in Early Modern England. Cambridge: Cambridge UP, 2009. Print.

Halberstam, Judith. In a Queer Time and Place: Transgender Bodies, Subcultural Lives. New York: New York UP, 2005. Print.

Halley, Janet, and Andrew Parker, eds. After Sex? On Writing since Queer Theory. Spec. issue of South Atlantic Quarterly 106.3 (2007): 421-646. Print.

Halperin, David M. How to Do the History of Homosexuality. Chicago: U of Chicago P, 2002. Print.

Hammill, Graham. Sexuality and Form: Caravaggio, Marlowe, and Bacon. Chicago: U of Chicago P, 2000. Print.

Harris, Jonathan Gil. "Untimely Meditations." Timely Meditations. Spec. issue of Early Modern Culture: An Electronic Seminar 6 (2007): n. pag. Web. 2007.

Hayes, Jarrod, Margaret Higonnet, and William J. Spurlin, eds. Comparatively Queer: Crossing Time, Crossing Cultures. New York: Palgrave, 2010. Print.

Herzog, Dagmar. "Syncopated Sex: Transforming European Sexual Cultures." American Historical Review 114.5 (2009): 1287-308. Print.

Hunt, Lynn. Measuring Time, Making History. Budapest: Central European UP, 2008. Print.

Jagose, Annamarie. “Feminism's Queer Theory." Feminism and Psychology 19.2 (2009): 157-74. Print.

Jeffreys, Elaine. Sex and Sexuality in China. London: Routledge, 2006. Print.

Lanham, Richard A. A Handlist of Rhetorical Terms. 2nd ed. Berkeley: U of California P, 1991. Print.

Lanser, Susan. "Mapping Sapphic Modernity." Hayes, Higonnet, and Spurlin 69-89.

—. "The Political Economy of Same-Sex Desire." Structures and Subjectivities: Attending to Early Modern Women. Ed. Joan E. Hartman and Adele Seeff. Newark: U of Delaware P, 2006. 157-75. Print.

. "The Sexuality of History: Sapphic Subjects and the Making of Modernity." N.d. TS.

Lochrie, Karma. Heterosynchrasies: Female Sexuality When Normal Wasn't. Minneapolis: U of Minnesota P, 2005. Print.

Love, Heather. Feeling Backward: Loss and the Politics of Queer History. Cambridge: Harvard UP, 2007. Print.

Manalansan, Martin F. "In the Shadows of Stonewall: Examining Gay Transnational Politics and the Diasporic Dilemma." GLQ: A Journal of Lesbian and Gay Studies 2.4 (1995): 425-38. Print. 
Menon, Madhavi. "Period Cramps." Afterword. Nardizzi, Guy-Bray, and Stockton, Queer Renaissance Historiography 229-35.

- Reply to letter of Carolyn Dinshaw and Karma Lochrie. PMLA 121.3 (2006): 838-39. Print.

—_. "Spurning Teleology in Venus and Adonis." GLQ: A Journal of Lesbian and Gay Studies 11.4 (2005): 491-519. Print.

- Unhistorical Shakespeare: Queer Theory in Shakespearean Literature and Film. New York: Palgrave, 2008. Print.

- Wanton Words: Rhetoric and Sexuality in English Renaissance Drama. Toronto: U of Toronto P, 2004. Print.

Muñoz, José Esteban. Cruising Utopia: The Then and There of Queer Futurity. New York: New York UP, 2009. Print.

Nardizzi, Vin, Stephen Guy-Bray, and Will Stockton. "Queer Renaissance Historiography: Backward Gaze." Nardizzi, Guy-Bray, and Stockton, Queer Renaissance Historiography 1-12.

_- eds. Queer Renaissance Historiography: Backward Gaze. Farnham: Ashgate, 2009. Print.

Paur, Jasbir Kaur. "Circuits of Queer Mobility: Tourism, Travel, and Globalization." GLQ: A Journal of Lesbian and Gay Studies 8.1-2 (2002): 101-37. Print.

Puff, Helmut. "After the History of (Male) Homosexuality." After the History of Sexuality: German Genealogies with and beyond Foucault. Ed. Scott Spector, Puff, and Dagmar Herzog. New York: Berghahn, 2012. 17-30. Print.

Radel, Nicholas F. Rev. of Queer Renaissance Historiography: Backward Gaze, ed. Vin Nardizzi, Stephen GuyBray, and Will Stockton. Renaissance Quarterly 63.3 (2010): 996-98. Print.

Rich, Adrienne. "Compulsory Heterosexuality and Lesbian Existence." Signs: A Journal of Women in Culture and Society 5.4 (1980): 631-60. Print.

Rofel, Lisa. Desiring China: Experiments in Neoliberalism, Sexuality, and Public Culture. Durham: Duke UP, 2007. Print.

Rohy, Valerie. Anachronism and Its Others: Sexuality, Race, Temporality. Albany: State U of New York P, 2009. Print.

Rubin, Gayle. "Thinking Sex: Notes for a Radical Theory of the Politics of Sexuality." Pleasure and Danger: Ex- ploring Female Sexuality. Ed. Carole S. Vance. London: Routledge, 1984. 267-319. Print.

Sanchez, Melissa E. Erotic Subjects: The Sexuality of Politics in Early Modern English Literature. Oxford: Oxford UP, 2011. Print.

Sang, Tze-lan D. The Emerging Lesbian: Female Same-Sex Desire in Modern China. Chicago: U of Chicago P, 2003. Print.

Sedgwick, Eve Kosofsky. Epistemology of the Closet. Berkeley: U of California P, 1990. Print.

. Tendencies. Durham: Duke UP, 1993. Print.

See, Sam. "Richard Barnfield and the Limits of Homoerotic Literary History." GLQ: A Journal of Lesbian and Gay Studies 13.1 (2007): 63-91. Print.

Stockton, Kathryn Bond. The Queer Child; or, Growing Sideways in the Twentieth Century. Durham: Duke UP, 2009. Print.

Stockton, Will. "How to Do the History of Heterosexuality: Shakespeare and Lacan." Literature Compass 7.4 (2010): 254-65. Print.

Playing Dirty: Sexuality and Waste in Early Modern Comedy. Minneapolis: U of Minnesota P, 2011. Print.

. "Shakespeare and Queer Theory." Rev. of Shakesqueer: A Queer Companion to the Complete Works of Shakespeare, ed. Madhavi Menon. Shakespeare Quarterly 63.2 (2012): 224-35. Print.

Traub, Valerie. “The Joys of Martha Joyless: Queer Pedagogy and the (Early Modern) Production of Sexual Knowledge." The Forms of Renaissance Thought: New Essays in Literature and Culture. Ed. Leonard Barkan, Bradin Cormack, and Sean Keilen. New York: Palgrave, 2008. 170-98. Print.

__. "Making Sexual Knowledge." Early Modern Women: An Interdisciplinary Journal 5 (2010): 251-59. Print.

. "The Present Future of Lesbian Historiography." A Companion to Lesbian, Gay, Bisexual, Transgender, and Queer Studies. Ed. George Haggerty and Molly McGarry. London: Blackwell, 2007. 124-45. Print.

Wah-shan, Chou. Tongzhi: Politics of Same-Sex Eroticism in Chinese Societies. London: Routledge, 2000. Print.

White, Hayden. Metahistory: The Historical Imagination in Nineteenth-Century Europe. Baltimore: Johns Hopkins UP, 1973. Print.

Wiegman, Robyn. Object Lessons. Durham: Duke UP, 2012. Print. 